\title{
Effect of Cooperative Learning Model Type of Group Investigation and Entry Behavior on Students' Biology Cognitive Competence in Senior High School (SMAN 5) Padang
}

\author{
Arini $^{1 *}$ Lufri $^{2}$ Ramadhan Sumarmin ${ }^{2}$ Syamsurizal ${ }^{2}$ \\ ${ }^{1}$ Student of Biology Education, Math and Natural Science Faculty, Universitas Negeri Padang, Padang, Indonesia \\ ${ }^{2}$ Biology Department, Math and Natural Science Faculty, Universitas Negeri Padang, Padang, Indonesia \\ ${ }^{*}$ Corresponding author. arini.orien@yahoo.com
}

\begin{abstract}
Purposes of the research were to know the effect of cooperative learning model type of Group Investigation and entry behavior on students' Biology cognitive competence and to investigate interaction between learning model and entry behavior towards students' cognitive competence learning outcomes in the human reproduction system and exclusive breastfeeding in family planning program learning materials. It was a quasi-experimental research by using purposive random sampling design. The population was all of XI MIPA students in SMAN 5 Padang registered on academic year 2018/2019. Samples were taken by using Purposive Sampling technique. As a result, class XI MIPA 5 was as experimental class (32 students) and class XI MIPA 6 was as control class (30 students).From data analysis using 2-tailed Annova test and LSD (Least Significance Different) test, it can be concluded that (1) cooperative learning model type of Group Investigation and entry behavior have positive effect on students' cognitive competence in the human reproduction system and exclusive breastfeeding in family planning program learning materials and (2) there is no interaction between learning model and entry behavior in improving students' cognitive competence learning outcomes in the human reproduction system and exclusive breastfeeding in family planning program learning materials.
\end{abstract}

Keywords: Cooperative; Group Investigation; Entry Behavior.

\section{INTRODUCTION}

Education is a process which has an important role in preparing qualified human resources. Education continues growing in line with the development of science and technology. Biology, as one of sciences, has important role in the science and technology development. Besides that, Biologyis also able to be applied in various fields of science, such as medical science, agricultural science, veterinary. To improve education quality, government has done some efforts, like curriculum improvement, teaching and learning facilities improvement, and teachers' quality improvement. In teaching and learning process, there are some elements which support it. One of them is teacher.

Teachers have important role in the success of learning process. A teacher is demanded to be able to plan and do learning process well. In addition,s/he are also demanded to have some competences, like mastering learning materials and using appropriate strategies in doing learning process.

According to Permendikbud No. 36 Year 2018 which discusses the 2013 Curriculum and Graduate Competency Standard of Elementary and Secondary Education, it explains that students' learning competences include cognitive, affective and psychomotor competences.

Based on interview with two Biology teachers in SMAN 5 Padang (Mrs. Yetri Yanofa, S.Pd, M.Si. andMrs. Sri Rahayu Andriyani, S.Pd.), it is known that students' learning competence is still low. It is obvious from the result of XI grade students' mid-term Biology test on academic year 2018/2019, as seen in Table 1 below.

Table 1. Data of XI Grade Students' Mid-term Biology Test Scores in SMAN 5 Padang on Academic Year $2018 / 2019$

\begin{tabular}{llll}
\hline Classes & $\mathrm{N}$ & $\begin{array}{l}\text { Average } \\
\text { Score }\end{array}$ & $\begin{array}{l}\text { Classical } \\
\text { Completeness } \\
(\%)\end{array}$ \\
\hline XI MIPA 1 & 31 & 71 & $13 \%$ \\
\hline XI MIPA 2 & 31 & 69 & $26 \%$ \\
\hline XI MIPA 3 & 30 & 72 & $23 \%$ \\
\hline XI MIPA 4 & 30 & 73 & $38 \%$ \\
\hline XI MIPA 5 & 32 & 74 & $38 \%$ \\
\hline XI MIPA 6 & 30 & 74 & $38 \%$ \\
\hline
\end{tabular}

Source: Biology Teacher in XI Grade of SMAN 5 Padang 
From Table 1 above, it is known that students' cognitive competence average scores in each class are still low. Meanwhile, average score of all classes is 72.16. It might be caused by some factors. First, lack of students' activeness during learning process, especially in discussion. There are only some students who are actively involved, while others do other activities, such as talk to their friends, do other subject exercises, and disturb their friends from other groups during discussion. Second, it still uses teacher-centered method, in which teacher uses conventional learning model. She explains learning materials using lecture method. Consequently, there is almost no interaction between teacher and students or between students and students. Third, there is no variation learning model used by teacher so that students become passive and less participated in learning process. Last, there is no reinforcement at the end of discussing activities.

The problems mentioned above need an appropriate solution to solve them. In order to create attractive and interesting learning atmosphere, it is necessary to implement an interesting learning model, such as cooperative learning model. The cooperative learning model is a learning model which focuses on the use of small groups of students to work together in maximizing learning situation to reach learning objectives ${ }^{[1]}$. One type of cooperative learning model is group investigation. The group investigation model could help students improve their ability in solving problems, make them more active in solving complex problems, and improve their learning motivation $^{[1]}$. Beside that, it is also a model which emphasizes on students' participation and activeness to search information about learning materials by themselves from available learning sources, such as books or websites in internet ${ }^{[1]}$.

The group investigation model has some advantages. First, it is a students-centered learning model. In implementing it, learning process is centered on students so that cooperation and interaction among students can take place without looking at their background ${ }^{[2]}$. Second, it can increase students' self-confidence to use their knowledge and skills in doing tasks or solving problems in their group $^{[3]}$. Third, it emphasizes on students' freedom in selecting topic and role in doing observation in their group and being responsible for what they have chosen. However, this learning model have never been implemented in school ${ }^{[4]}$. Fourth, it can facilitate students to develop their skills in doing investigation, arranging a report, and discussing in the classroom so that they can train their creative thinking and responsibility in group and learn to obtain scientific knowledge through group activities by doing investigation and innovation ${ }^{[5]}$. Fifth, it can also improve students' responsibility for what they have chosen, cooperative and communicative skills, and participation in discussion so that their activeness in learning process can improve their learning outcomes ${ }^{[2]}$.

Other factor which might affect students' cognitive competence is their entry behavior. It can affect students on interpreting new information and deciding whether information is relevant or not ${ }^{[6]}$. In learning process, entry behavior is used to relate concept which have been understood by students to new concept they are going to learn ${ }^{[6]}$. Moreover, it can also determine whether information and concept they have are related to new knowledge or materials they are studying ${ }^{[7]}$.

In Natural Science learning, especially Biology, students' entry behavior also affects their success in learning because Biology learning materials, generally, are arranged hierarchically, one materials is prerequisite of the next materials ${ }^{[2]}$. In other words, students who do not understand the prerequisite materials will have difficulty in understanding the next materials which need it. Those who have entry behavior about concepts related to new learning materials will be enthusiastic in learning the materials because they have understood the concept related to the materials.

Based on the background of the problems explained above, it was formulated into "Do group investigation model and entry behavior have positive effect on students' outcomes in cognitive competence?" and "Is there any interaction between learning model and students' entry behavior?". The purposes of the research were to know positive effect of cooperative learning model type of Group Investigation and entry behavior on students' Biology cognitive competence and to investigate interaction between learning model and entry behavior towards students' cognitive competence learning outcomes in the human reproduction system and exclusive breastfeeding in family planning program learning materials. The hypotheses of this research were group investigation model and entry behavior have positive effect on students' cognitive competence and there is an interaction between learning model and students' entry behavior.

\section{METHODS}

It was a quasi-experimental research by using $2 \times 2$ factorial Design, which means one class is treated by using Group Investigation model $\left(\mathrm{A}_{1}\right)$ as experimental group and another class is treated by using conventional model $\left(\mathrm{A}_{2}\right)$. In each class, students were categorized based on their entry behavior, which were high Entry behavior students $\left(B_{1}\right)$ andlow entry behavior students $\left(B_{2}\right)$. The population was all of XI MIPA students in SMAN 5 Padang registered on academic year 2018/2019. Samples were taken by using Purposive Sampling technique. As a result, class XI MIPA 5 was as experimental class (32 students) and class XI MIPA 6 was as control class (30 students). Instrument used was a multiple-choice test.In data analysis, it used 2-tailed Annova test by using SPPS 16 software. If result of the Annova test was significant, it was continued to LSD (Least Significant Different) test to see which group was different significantly. 


\section{RESULT AND DISCUSSION}

Evaluation of students' cognitive competence is done after all learning materials about the human reproduction system and exclusive breastfeeding in family planning program have been taught. Instrument used was a multiple-choice test, consisted of 25 question items. Results of the test, then, are grouped based on students' entry behavior. In each class, it is grouped into high entry behavior and low entry behavior. The grouping of students' cognitive competence learning outcomes based on the entry behavior can be seen in Table 2 below.

Table2.Data of Cognitive Competence Average Score Based on Students' Entry Behavior in Sample Classes

\begin{tabular}{llll}
\hline Class & Entry Behavior & $\overline{\boldsymbol{x}}$ & SD \\
\hline \multirow{2}{*}{ Experimental } & High & $94.44^{\mathrm{a}}$ & 3.41 \\
& Low & $82.25^{\mathrm{b}}$ & 3.17 \\
\hline \multirow{2}{*}{ Control } & High & $86.40^{\mathrm{b}}$ & 5.71 \\
& Low & $73.27^{\mathrm{c}}$ & 3.76 \\
\hline
\end{tabular}

Description:

$\overline{\mathrm{x}} \quad$ : Average Score

SD : Standard Deviation

Based on data in Table 2 above, it is obvious that in experimental class, average score of high entry behavior students is 94.44 andof low entry behavior students is 82.25. Meanwhile, in control class, average score of high entry behavior students is 86.40 andof low entry behavior students is 73.27. So, it shows that average scores of both high and low entry behavior students in experimental class are higher than average scores of both high and low entry behavior students in control class. It can be seen in Table3 below.
Table3. Result of 2-tailed Annova Test of Students' Cognitive Competence and Entry Behavior in Sample Classes

\begin{tabular}{lllll}
\hline Parameter & $\begin{array}{l}\text { Mean } \\
\text { Square }\end{array}$ & F & Sig. & Description \\
\hline $\begin{array}{l}\text { Class } \\
\text { (Model) }\end{array}$ & 1121.45 & 66.54 & 0.00 & Significant \\
\hline $\begin{array}{l}\text { Entry } \\
\text { Behavior }\end{array}$ & 2481.85 & 147.27 & 0.00 & Significant \\
\hline $\begin{array}{l}\text { Class*Entr } \\
\text { y Behavior }\end{array}$ & 3.46 & 0.21 & 0.65 & $\begin{array}{l}\text { No } \\
\text { Interaction }\end{array}$ \\
\hline
\end{tabular}

Based on Table 3 above, it is obvious that in parameter of class, F score is 66.54 with sig.value $0.00<\alpha$ so that it can be concluded that there is a significant difference between students' cognitive competence score in experimental class and in control class. Next, in parameter of entry behavior, F score is 147.27 with sig.value $0.00<\alpha$ so that it can be concluded that there is a significant difference between cognitive competence score of high entry behavior students and low entry behavior ones. Last, in parameter of interaction between class and entry behavior, $\mathrm{F}$ score is 0.21 with sig.value $0.65>\alpha$ so that it can be concluded that there is no interaction between learning model and entry behavior in improving students' cognitive competence learning outcomes in the human reproduction system and exclusive breastfeeding in family planning program learning materials. So, since parameters of class and entry behavior have significant effect, an advanced test to know which group is different significantly is conducted. It is Least Significant Different (LSD) test using SPSS 16 software. The result of the test can be seen in Table4 below.

Table4. Result of LSD Test in Experimental and Control Classes

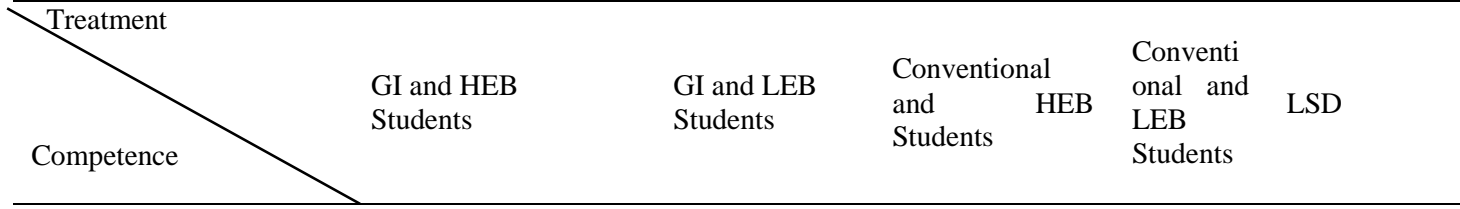

GI andHEB Students

GI and LEB Students 12.19*

\begin{tabular}{llll}
$\begin{array}{l}\text { Conventional and HEB } \\
\text { Students }\end{array}$ & $8.04^{*}$ & $4.15^{\mathrm{NS}}$ & - \\
\hline $\begin{array}{l}\text { Conventional and LEB } \\
\text { Students }\end{array}$ & $21.17^{*}$ & $8.89^{*}$ & $13.13^{*}$ \\
\hline
\end{tabular}

\section{Description: HEB = High Entry Behavior}

LEB $=$ Low Entry Behavior

LSD $=$ Least Significant Different 
Based on Table4 above, it shows that there is a significant difference in students' entry behavior groups, which is explained in detail as follows: first, high entry behavior students who used group investigation model and low entry behavior students who used group investigation model get $12.19>5.81$, which means that there is a significant difference between them. Second, high entry behavior students who used group investigation model and high entry behavior students who used conventional model get $8.04>5.81$, which means that there is a significant difference between them. Then, high entry behavior students who used group investigation model and low entry behavior students who used conventional model get $21.17>5.81$, which means that there is a significant difference between them. Next, low entry behavior students who used group investigation model and high entry behavior students who used conventional model get $4.15<5.81$, which means that there is no significant difference between them. After that, low entry behavior students who used group investigation model and low entry behavior students who used conventional model get $8.89>5.81$,which means that there is a significant difference between them. Last, high entry behavior students who used conventional model and low entry behavior students who used conventional model get 13.13 $>5.81$, which means that there is a significant difference between them. So, based on the results above, it can be concluded that almost all of the groups are different significantly, except low entry behavior students in experimental class with high entry behavior students in control class.

However, the learning model used does not give effect on students' entry behavior. Group of high entry behavior students in experimental class treated by group investigation model has better improvement than group of high entry behavior students in control class treated by conventional model. It is similar to group of low entry behavior students in experimental class treated by group investigation model has higher learning outcomes than group of low entry behavior students in control class treated by conventional model.

Based on the result of hypothesis testing, it is known that cooperative learning model type of group investigation and entry behavior can improve students' cognitive competence. A strength of GI model is that it can increase students' self-confidence to use their knowledge and skills for their groups[3]. In its implementation, GI model focuses on students' freedom to select topic, role and responsibility in doing observation in their group; while, in school, it has never been implemented[4].

High entry behavior students' cognitive competence average score is higher than of low entry behavior ones. Due to significant difference of students' learning outcomes according to 2-tailed Annova test (Table 3), Least significant different (LSD) is conducted to show whether there is a significant difference between entry behavior group or not. It is obvious from the group score ofFcount> 5.81, which means that there are five groups which are significantly different and one group which is no significantly different.
Besides that, cooperative learning model type of group investigation and entry behavior give a positive effect on students' Biology cognitive competence because it can improve their knowledge about Biology. It is caused by the model and entry behavior facilitate them in learning process. The Group Investigation model is a cooperative learning model which emphasizes on students' participation and activities to search information about learning materials they are going to learn through available sources, such as books or websites in internet[8]. In addition, students are involved from planning the lesson, both in selecting topic and method to learn it through investigation[8]

Another research found that students' entry behavior affects their learning outcomes. High entry behavior students get better learning outcomes than low entry behavior students [9]. Students' entry behavior is seen from result of preliminary test [10]. It is very important for teacher in order to give appropriate, not too easy or not too difficult, learning materials [10]. Also, it is useful to take necessary steps to understand new competence [10]. In conclusion, students' entry behavior is a foundation for students before learning new materials which can raise responds or reaction during learning process so that it can create better interaction in the classroom [10].

Next, the result of 2-tailed Annova test about interaction between class and entry behavior (Table 3) shows that sig.value $>0.05$. So, hypothesis which states that there is an interaction between learning model and entry behavior towards learning outcomes in cognitive competence is rejected. It means that interaction between learning model and entry behavior has no significant effect on students' learning outcomes in cognitive competence.

The different learning outcome in high and low entry behavior might be caused by the difference of time use needed by high entry behavior students since in group investigation model and entry behavior, they are involved actively in thinking process during learning. Through learning group, they can understand learning materials better because they are given an opportunity to find or search learning materials by themselves in their home before being explained by teacher in the classroom.

There are some factors which can improve students' learning outcomes through group investigation model[11]. First, it emphasizes that each group has a freedom to select a topic provided by teacher. By selecting the topic, each group has different knowledge about it so that every student gets direct experience about topic they discuss[11].Second, it emphasizes that students need to work together in group[11]. Each student has to be responsible on their job because each group is going to present their discussion result in front of the classroom [11]. In group discussion, every student needs to be responsible to do the best for their group[12]. Third, it gives an opportunity to every group to present their result of discussion in front of the classroom [11]. Through it, students can appreciate differences, learn from each other and share their opinion each other[12].Evaluation in this learning model can give advantage, especially, to implementation and effectiveness of learning program[11]. 
The evaluation functions to know effectiveness of the program in establishing its objectives and to identify parts of learning that should be improved [13].

Students' higher participation in Group investigation model and entry behavior might be caused by they have understood concepts of learning materials they learn in the classroom. It can also make them learn more meaningfully. Good understanding of learning materials that have been studied and is going to be studied can increase their interests and motivation to follow instruction. It can give good effect on their learning outcomes. It is in line with an opinion which stated that group investigation model and entry behavior make students more motivated in learning Biology [11]. Moreover, the model can improve solidarity among students [11]. High entry behavior students will help and share their knowledge to low entry behavior students in discussion and analysis activities. As a result, low entry behavior students will be more motivated to use the provided opportunity for them [12].

The finding of this research shows that high entry behavior students who treated by group investigation model are better than high entry behavior students who used conventional model. It can be caused by some factors, as follows: 1) Scores of high entry behavior students in experimental class are higher than score of high entry behavior students in control class; 2) Students treated by group investigation model are more active than those who treated by conventional model. It is because students treated by group investigation model work in group, discuss, share ideas each other about the learning materials, while those who treated by conventional model only listen to teacher's explanation; 3 ) high entry behavior students treated by group investigation model are more focused on the discussed provided problems so that they try to solve the problem by sharing information with their group members, while high entry behavior students treated by conventional model are focused only on a general problem and they tend to be passive in learning process; 4) Learning process of students treated by group investigation is more interesting through discussing and sharing ideas and opinion. All questions and answers get equal appreciation so that it creates intact conclusion in solving

\section{CONCLUSION}

Based on findings and discussion above, it can be concluded that (1) cooperative learning model type of Group Investigation and entry behavior have positive effect on students' cognitive competence in the human reproduction system and exclusive breastfeeding in family planning program learning materials and (2) there is no interaction between learning model and entry behavior in improving students' cognitive competence learning outcomes in the human reproduction system and exclusive breastfeeding in family planning program learning materials. problem. Meanwhile, learning process of students treated by conventional model tends to be not active and boring[14].

Similarly, for low entry behavior students, the use of group investigation model is more effective to improve their cognitive competence than the use of conventional model[14]. It might be caused by low entry behavior students treated by group investigation model can communicate freely to their friends from other groups, not only to their friends in same group so that they get a lot of explanation related to the human reproduction system and exclusive breastfeeding in family planning program learning materials.

The difference of learning outcomes for students who have high entry behavior and low one could be caused by the difference of time use needed by them to understand learning materials. The high entry behavior students are easier to develop their knowledge than the low entry behavior ones since in the implementation of group investigation, they are involved in thinking process to solve problems and to arrange work plan[14]. They can think, understand a concept and analyze learning material faster than low entry behavior students[14].

Other research also found that the higher entry behavior followed by high learning motivation owned by students, the higher learning outcomes they get. In contrast, the lower entry behavior followed by low learning motivation, the lower learning outcomes they get[15]. One of advantages of entry behavior is it can help students to relate to new concepts they learn so that good understanding can be developed by them[11,14].

Group investigation model gives an opportunity for students to develop their own concept through various learning sources so that they not only memorize the concept. Furthermore, learning using group investigation model invites students to solve a problem through investigating various learning sources, like laboratory, which make them more active to find solutions of the problem so that they have better understanding about what they do.So, based on the explanation above, it is clear that cooperative learning model type of group investigation gives positive effect on students' Biology learning outcomes in cognitive competence.

\section{REFERENCES}

[1] Aguanta Jr, E. R., and Tan, D. A. 2018. Effects of Dyad Cooperative Learning Strategy on Students' Academic Performance and Attitude towards Mathematics. International Journal of English and Education, 7(3), 303-313.

[2] Wahyuningsih, I. 2017. Pengaruh Model Pembelajaran Kooperatif Tipe Goup Investigation Terhadap Hasil Belajar IPA. Natural: Jurnal Ilmiah Pendidikan IPA, 4(1), 26-33.

[3] Eom, S. B., Wen, H. J., and Ashill, N. 2006. The Determinants of Students' Perceived Learning Outcomes and Satisfaction in University Online 
Education: An Empirical Investigation. Decision Sciences Journal of Innovative Education, 4(2), 215-235.

[4] Aprilia, I. 2016. Pengaruh Model Pembelajaran Kooperatif Tipe Group Investigation (GI) terhadap Hasil Belajar Siswa dalam Pembelajaran Biologi pada Materi Ekosistem di Kelas VII Semester II MTsN 1 Palangka Raya Tahun Pelajaran 2014/2015. Edu Sains: Jurnal Pendidikan Sains \& Matematika, 3(2). 76-79.

[5] Suartika, K., Arnyana, I. B., and Setiawan, G. A. 2013. Pengaruh Model Pembelajaran Kooperatif Tipe Group Investigation (GI) terhadap Pemahaman Konsep Biologi dan Keterampilan Berpikir Kreatif Siswa SMA. Jurnal Pendidikan dan Pembelajaran IPA Indonesia, 3(1). 112-118.

[6] Masri, M. F., Suyono, S., and Deniyanti, P. 2018. Pengaruh Metode Pembelajaran Berbasis Masalah terhadap Self-Efficacy dan kemampuan Pemecahan Masalah Matematis Ditinjau dari Kemampuan Awal Matematika Siswa SMA. Jurnal Penelitian dan Pembelajaran Matematika, 11 (1).156-158.

[7] Herawati, R. F., Mulyani, S., and Redjeki, T. 2013. Pembelajaran Kimia Berbasis Multiple Representasi Ditinjau dari Kemampuan Awal terhadap Prestasi Belajar Laju Reaksi Siswa SMA Negeri I Karanganyar Tahun Pelajaran 2011/2012. Jurnal Pendidikan Kimia (JPK), 2(2). 34-45.

[8] Sulasti, N. W. 2013. Penerapan Model Pembelajaran Kooperatif Tipe Group Investigation (GI) untuk Meningkatkan Aktivitas dan Hasil Belajar Siswa dalam Pelajaran PKn di Kelas XI IPA 1 SMA Negeri 1 Sawan Tahun Ajaran 2012/2013. Jurnal Pendidikan Kewarganegaraan Undiksha, 1 (4). 26-32.

[9] Rachmadiati, R. I. 2017. Pengaruh Penerapan Metode Problem Solving dan Metode Group Investigation terhadap Kemampuan Berpikir Kritis Siswa Dilihat dari Kemampuan Awal. Indonesian Journal of Education (IJEE), 1(1).

[10] Harjanto. 2006. Perencanaan Pembelajaran. Jakarta: Rineke Cipta.

[11] Setyaningsi, R. 2013. Penerapan Model Pembelajaran Group Investigatiom untuk Meningkatkan Motivasi dan Hasil Belajar Pesawat Sederhana pada Siswa Kelas V Sekolah Dasar Negeri 3 Selakambang Kabupaten Purbalingga. Skripsi. UNNES: Pendidikan Guru Sekolah Dasar.

[12] Lie, Anita. 2016. Cooperative Learning. Jakarta: PT. Gramedia Widiasara Indonesia (Grasindo).

[13] Ibrahim, M. 2013. Pembelajaran Kooperatif. Surabaya: Unesa.

[14] Irawati, R. K. 2014. Pengaruh Model Problem Solving dan Kemampuan Awal terhadap
Hasil Belajar Siswa. Jurnal Pendidikan Sains, 2 (4), 184-192.

[15] Lestari, W. 2017. Pengaruh Kemampuan Awal Matematika dan Motivasi Belajar terhadap Hasil Belajar Matematika. Jurnal Analisa, 3 (1), 76-84. 